\title{
Settling Defaults in the Era of Bond Finance
}

\author{
Barry Eichengreen and Richard Portes
}

Comparisons of the debt crises of the 1930s and 1980 s emphasize the greater incidence of default and the greater ease of restructuring half a century ago. The difficulty developing-country debtors have had in putting the current crisis behind them, it is argued, is due to the more systematic involvement of creditor-country governments and intergovernment agencies. This article reviews the negotiating strategies of the debtors and creditors of the 1930s, the terms of settlement, and the realized rates of return on U.S. and U.K. foreign bonds. It shows that rather than being sharp and complete, default in the 1930 s was often partial and intermittent. Uncertainty about debt, trade, and export credits lingered on. Often many years passed before final settlements were achieved. Creditor-country governments were intimately involved in the settlement process, although their influence was not always to the benefit of the bondholders.

Imagine a counterfactual where banks and countries had been left alone to work out their differences, with the central banks of industrialized countries and the IMF limiting themselves to a strict lender of last-resort function . . . A sharp restructuring period would have cleared up much of the excess debt burden, with both lenders and borrowers suffering from their bad forecasts.

$$
\text { Diaz-Alejandro (1987, p. 25) }
$$

The parallels between the current debt crisis in developing countries and its predecessors have been widely remarked upon. The surge of foreign lending in the 1970s, the sudden appearance of debt-servicing difficulties in the 1980s, and the proposals that have been offered to put the crisis behind us by the 1990 s all bear an eerie resemblance to previous episodes in which transfer crises

Barry Eichengreen is a professor of economics at the University of California, Berkeley, and a research fellow of the Centre for Economic Policy Research (CEPR), London. Richard Portes is a professor of economics at Birkbeck College, University of London and director of the CEPR. An earlier version of this article was presented to a conference, "A Long-Run Perspective on the International Debt Crisis," San Francisco, May 27, 1988. The authors thank Andrew Brociner, Tony Humm, Mara Leounaki, and Carolyn Werley for assistance, the Council of Foreign Bondholders for permission to cite materials from their archives, and Benjamin Cohen, Michael Edelstein, Thomas Huertas, Richard Kohl, Peter Lindert, and three anonymous referees for comments. This article is part of a project on the history of developing-country debt, funded in part by a research grant from the World Bank to the Centre for Economic Policy Research.

(C) 1989 The International Bank for Reconstruction and Development / THE WORLD BANK. 
disrüpted the smooth functioning of the international capital market. But some suggest that the current debt crisis differs from those of the $1870 \mathrm{~s}, 1890 \mathrm{~s}$, and 1930 s in one fundamental respect. In these earlier crises, it is claimed, debtservicing difficulties culminated in a unilateral and complete suspension of interest and amortization payments. A sharp restructuring period then followed and cleared up much of the excess debt burden, as in Diaz-Alejandro's counterfactual. The 1930s, when some two-thirds of foreign dollar bonds and onethird of overseas sterling issues lapsed into default, are invoked as the most dramatic illustration of the general point (see, for example, Sachs 1986; Skiles 1988 ). In the $1980 \mathrm{~s}$, in contrast, debtors and creditors have continued to muddle through. Aided by a variety of expedients, including serial reschedulings, forced lending by the banks and supplementary funds from the international institutions, and at considerable expense to themselves, the debtors so far have succeeded in warding off formal default.

Is this current avoidance of widespread default due to the increased involvement of creditor-country governments? In the nineteenth century, governments had at best an ambivalent attitude toward intervention on behalf of their investors. Admittedly, the exertion of influence by U.K. officials on behalf of bondholders was not unknown. The entanglements to which the interplay of economic and strategic interests could lead are epitomized by the establishment of a U.K. protectorate in Egypt. The French and German governments were more willing still to intervene on behalf of investors (Fishlow 1986), and the United States sent in the Marines when U.S. foreign investments in the Caribbean or Central America were threatened. But in nearly all of these instances, economics was merely an excuse for intervention desired on other, usually military or strategic, grounds.

By the 1930 s, government resistance to pressures for intervention had hardened. The Roosevelt Administration attached priority to the removal of trade restrictions, precluding sanctions against defaulting debtors, and adopted a policy of official noninterposition in negotiations between U.S. bondholders and foreign governments. With a few notable exceptions, the U.K. government too continued to regard default as a private matter (Royal Institute of International Affairs 1937). The use of military force for debt collection was basically a thing of the past. In a 1937 report, the U.S. Securities and Exchange Commission advised U.S. bondholders to eliminate this possibility from their consideration.

In the $1980 \mathrm{~s}$, the argument continues, the government of the leading creditor country, the United States, has "aggressively managed the debt crisis with a view towards maintaining continued debt servicing" (Sachs 1986; see also Lindert and Morton 1988). Its objective has been to buttress the U.S. banking system, which is more vulnerable to destabilization by nonperforming foreign loans than at any time in the past. (The relative size of foreign lending by the United States, United Kingdom, and countries belonging to the Organisation for Economic Co-operation and Development (OECD) in the two periods is 
Table 1. Foreign lending, 1920-31 and 1973-82

\begin{tabular}{|c|c|c|}
\hline Foreign capital issues & $\begin{array}{c}\text { U.S. } \\
\text { (New York) } \\
\text { lending }\end{array}$ & $\begin{array}{c}\text { U.S. plus U.K. } \\
\text { (London) } \\
\text { lending }\end{array}$ \\
\hline \multicolumn{3}{|l|}{$1920-31$} \\
\hline Annual average (millions of dollars) & 2,268 & 3,670 \\
\hline \multirow[t]{2}{*}{ As a percentage of lenders' GNP } & 0.21 & $0.28^{\mathrm{a}}$ \\
\hline & & $\begin{array}{c}\text { Total private lending to } \\
\text { non-oil-exporting developing }\end{array}$ \\
\hline $1973-82^{c}$ & U.S. lending ${ }^{\mathrm{b}}$ & countries \\
\hline Annual average (millions of dollars) & 23,780 & 55,900 \\
\hline As a percentage of lenders' GNP & 0.55 & $0.51^{\mathrm{d}}$ \\
\hline
\end{tabular}

$\mathrm{GNP}=$ gross national product; $\mathrm{GDP}=$ gross domestic product.

a. Sterling figures converted to dollars at current exchange rates.

b. Calculated assuming that U.S. share of total lending in 1975-80 applies to entire period.

c. Converted to 1920-31 prices using U.S. Department of Commerce GNP deflators.

d. Using GDP of OECD countries.

Source: U.S. 1920-31 GNP deflators from U.S. Department of Commerce (1976). U.K. 1920-31 GNP based on data from Feinstein (1972). U.S. 1973-82 lending based on IMF (1983, p. 22) and Porzecanski (1983). Total 1973-82 OECD lending from IMF (1983, p. 22) and OECD (various years).

indicated in table 1.) The U.S. government has made clear the importance it attaches to the maintenance of debt service, through individual discussions with debtor countries, by enlisting the support of other governments in Paris Club negotiations, and by floating proposals such as the Brady and Baker plans. Foreign policymakers have reason to fear that default might trigger trade sanctions and curtail official development assistance and official export credits, and this may have prevented the debtors from forcing the sharp restructuring that would have quickly put the debt crisis behind them.

The influence of governments has been reinforced, it is alleged, by the coordinating role of the International Monetary Fund (IMF) (again, see Sachs 1986; see also Lindert, forthcoming). In the nineteenth century there existed no comparable institutions. In the 1930s, the Bank for International Settlements (BIS) played a part in organizing international loans to European countries experiencing balance of payments crises. But the financial role of the BIS was tightly circumscribed, and it was preoccupied not with debt problems per se but with threats to the stability of the exchange rate system. In the $1980 \mathrm{~s}$, in contrast, IMF programs are normally a prerequisite to commercial bank rescheduling, to World Bank structural adjustment loans, and to Paris Club agreements to reschedule bilateral intergovernmental obligations. ${ }^{1}$ In turn, the IMF has required that countries come to terms with the banks to prevent the IMF loan from simply going to commercial debt service. Because a Fund loan hangs in

1. There have been exceptions, notably Mozambique, Poland, and Cuba (which is not an IMF member). There have also been a limited number of occasions on which the banks have not required an IMF agreement. This remains the general rule, however. 
the balance, the banks have greater leverage in their efforts to obtain favorable terms, whereas the debtor has added incentive to avoid default. The implication is that, absent creditor country and IMF involvement, the dramatic alternatives to muddling through that Diaz-Alejandro suggests would have been more likely, and these would have helped all parties to put the debt crisis behind them, thereby setting the stage for renewed growth in the borrowing regions.

The greater incidence of default in the 1930 s than in the 1980 s cannot realistically be attributed to the relative magnitude of shocks to the debtors' economies. From the perspective of Latin America's debt-servicing difficulties, the disturbances of the early 1980s were of comparable magnitude to those of the 1930s (Diaz-Alejandro 1983; Eichengreen and Portes 1987). The obvious difference-the behavior of export volumes, which fell dramatically after 1929 but have continued to rise in the present crisis-is attributable at least in part to the response of Latin American countries, which have made great efforts to expand exports to service debt, as well as to differences in the global economic environment.

It may also appear that default was more common in the 1930 s because it was difficult to mobilize new money in the era of bond finance. Lending through the bond market can create a free-rider problem for the provision of new money. Extrapolating from estimates of Dwight Morrow, in 1937 the U.S. Securities and Exchange Commission (1937, p. 6) conjectured that up to 700,000 investors held foreign bonds in default. Thus even if it had been in the interest of foreign bondholders collectively to provide additional liquidity to the borrowing country, there was no way to mobilize the multitude of bondholders or to compel them to contribute. Bank lending creates free-rider problems of its own-Fischer (1988) notes that 500 banks were involved in the September 1986 Mexican agreement, and six months or more were required for all of them to sign on. But the presence of a few large creditors provides opportunities to buy out the smaller participants or to compel their cooperation, and new lending could result. This new money, it is argued, could then prevent outright default and induce debtors to put macroeconomic adjustment programs in place.

The problem with this argument is that new money has been forthcoming in quantities insufficient to offset the resource transfers to the creditors. Although there is no doubt that this transfer and the associated difficulties would have been greater still in the absence of forced lending, such a small incentive cannot explain why the indebted countries have resisted default. Thus, to explain the difference between periods investigators ultimately return to the extent of government involvement.

Our purpose in this article is to scrutinize both strands of the received wisdom: that which draws a strong contrast between the 1930s and 1980s in the extent of default and ease of settlement, and that which attributes the difference to greater government involvement today. Although we do not reject outright either of these strands, we argue that both must be strongly qualified. 
Rather than being sharp and complete, default in the 1930 s was often partial and intermittent. Uncertainty about debt, trade, and export credits lingered on. Often many years passed before final settlements were achieved (see appendixes $A$ and B). In addition, creditor-country governments were often intimately involved in the process of debt negotiation.

We consider a number of institutional factors influencing the ease of settlement, including the extent of overlap between creditors extending export finance and long-term loans, bilateral negotiations between borrowing governments and bondholders' representative committees, repurchases of existing liabilities by the debtor, and the role of national divisions within the creditor community, at both the bondholder and the government levels. Because much of the material upon which we draw comes from the archives of the U.K. bondholders' representative committee, the Corporation of Foreign Bondholders ( $\mathrm{CFBH})$, we concentrate on the settlement of U.K. debts.

\section{Negotiating on Behalf of Bondholders}

In the 1930s, defaults on foreign bonds were generally settled through negotiations between foreign borrowers and committees representing the bondholders. Rather than repudiate their debts, governments typically announced that unforeseen circumstances had forced them to suspend or reduce interest and amortization. Settlement was similarly ambiguous. If they desired to initiate negotiations, officials of the debtor government contacted the committee representing the bondholders. Typically, that committee would dispatch a representative to the debtor country to negotiate with local officials, often to establish a new schedule of interest and principal repayments. Upon the conclusion of negotiations satisfactory to the committee, it would issue a public recommendation that bondholders indicate their acceptance of the offer by cashing coupons or submitting bonds for exchange. Bondholders dissatisfied by the terms could choose to hold out for better ones, as some do to this day. ${ }^{2}$

By the 1930s, the Corporation of Foreign Bondholders ( $\mathrm{CFBH}$ ), founded in : 1868 , was universally acknowledged to represent sterling bondholders. Although initially dominated by representatives of the banks and brokers, by the onset of the 1930s wave of defaults the CFBH governing Council had come to include representatives of the Association of Investment Trusts, the British Insurance Association, the Bank of England, and the stock exchange (U.S. Securities and Exchange Commission 1937, pp. 39-53).

Initially, much of the influence of the Council derived from its intimate relations with the stock exchange. One of the exchange's rules was to refuse quotation to new loans of governments which had defaulted and failed to settle

2. Often the market for unassented bonds would shrink as the deadline for acceptance (usually five years) approached and the bonds' option value depreciated. But these deadlines were not a universal feature of the terms of offer. 
with their creditors, and in extreme instances to strike from the list all loans of the offending government (see Jenks 1927; Feis 1930, pp. 114-15). Although some trading in London took place outside the stock exchange and although new loans conceivably could be floated in other markets, lack of access to the London market was a serious sanction.

In the United States, where foreign flotations were a new development, there existed no comparable organization until 1933. Instead, ad hoc committees were established to negotiate with each foreign government. These temporary committees had high administrative expenses, lacked the authority to speak credibly for the bondholders, and rarely possessed good relations with the U.S. government or ties with the stock exchange. In response to these shortcomings and because correspondence with bondholders was absorbing so much staff time, in 1932-33 the U.S. State Department sponsored the formation of a committee to draw up plans for a standing organization. That new organization, the Foreign Bondholders Protective Committee (FBPC), was founded in 1933 and financed by contributions from charitable foundations and the stock exchange until commissions rendered it self-sustaining.

Comparable associations existed in France, Germany, and other countries. The CFBH saw clearly the advantage of a creditors' cartel in the face of widespread default; there was "no question that in theory cooperation between all the Bondholders' organizations is most desirable and that such cooperation is more than ever necessary in view of the present attitude of the debtors . . . the debtor not infrequently managed to pay in all, less than he would have been willing to do had there been no difference of opinion among the Bondholders' Organizations" [Minutes of the Council of the Corporation of Foreign Bondholders (hereinafter "Minutes"), file entitled "Cooperation," Nov. 25, 1937]. Although cooperation between the CFBH and its continental counterparts was relatively well developed, relations between the European and U.S. committees were strained. Sterling and dollar bond covenants differed significantly in their interest rates and in the security offered by the borrower. Hence the U.K. and U.S. committees disagreed on the appropriate treatment for different types of bonds (see section IV). The CFBH was critical of its U.S. counterpart for settling unilaterally, leaving the British no choice but to accept the same terms. It complained that communication by telephone was expensive and unsatisfactory and that the president of the FBPC often failed to respond to letters in timely fashion.

The committees sought to maximize the value of the assets of the bondholders. To this end they opposed writing down principal, forgiving interest arrears, and yielding concessions on future interest payments. The first two points were presented as matters of principle. It was fine to reduce future interest payments if bondholders accepted such offers voluntarily, but inappropriate to write off capital or interest arrears, since these obligations had been incurred before renegotiation of the bond covenants. But in practice the CFBH was willing to trade principal and interest arrears incurred in the past for more favorable 
treatment in the future. In 1940, for example, the Council agreed to inform the Ecuadorean negotiator that "the Council might be prepared to abandon the arrears if he would put forward a reasonable offer for the future service of the debt ..." (Minutes, Ecuador, May 19, 1940). In 1943 the Council negotiated an agreement with Brazil under which bondholders could opt for writing off principal in return for a cash payment and a higher interest rate.

The debtors tried to minimize damage to their credit owing to protracted default. As the U.S. Securities and Exchange Commission put it in 1937, "The willingness of the issuer to negotiate with representatives of the bondholders and eventually to agree to readjust its default generally has two motivations: a desire to restore the prestige and reputation of the nation, and a desire to borrow more money" (U.S. Securities and Exchange Commission 1937, p. 31). It was in the bondholders' interest to emphasize the implications of settlement for market access. In its negotiations with Brazil, the CFBH "explained how impossible it would be for Brazil to recover and prosper without the goodwill of foreign capitalists." But debtors' willingness to enter into negotiations depended both on the state of the international capital market-since damage to one's credit mattered little in periods when creditors were unwilling to lendand on the value attached to the ability to borrow relative to other objectives. As Sir Henry Lynch, Rothschild \& Sons' representative in Brazil, explained this to the CFBH in 1936, "The Brazilians knew that they had no credit and ... they thought therefore that they might as well cease payments on their External Debt. There were many people who wished to devote sums now used to pay interest to the internal needs of the Country and they were exerting strong pressure on the President and the Finance Minister to cease payments" (Minutes, Brazil, Oct. 27, 1936; Minutes, Brazil, Dec. 9, 1937).

Similar sentiments were again conveyed to the Council by their Brazilian negotiator in 1942. There was a strong bias in Brazil, especially within the Army, against "wasting money on the foreign debt. The importance to Brazil of maintaining her credit did not greatly impress many Brazilians, since Brazil seemed able in any case to obtain as much money as she required from the U.S.A. The Finance Minister and Senor Oswaldo Aranha were more orthodox but their main concern was to reduce the debt as much as possible and meanwhile to pay interest only enough to prevent the debt being too dark a stain on

: $\quad$ Brazil's escutcheon" (Minutes, Brazil, Sept. 18, 1942).

\section{The Role of Governments}

The role of governments in these negotiations was more complex than formal statements of their hands-off attitude would suggest. Even when otherwise uninvolved, governments played an informational role. The FBPC regularly obtained information on the local situation from the U.S. State and Commerce departments. Local embassy staff and the Foreign Office in London provided information on local economic conditions to the CFBH. The information could 
be quite specific. In 1938, for example, an official of the South American Department of the British Foreign Office suggested to the CFBH "that it would be helpful if somebody from the Council went out to Brazil. He was naturally discreet, but it seemed clear that his view was that both Sir Hugh Gurney [Ambassador to Brazil] and Sir Henry Lynch [then the CFBH's negotiator] had become unduly influenced by Brazilian opinion and needed stiffening by personal contact with a representative of the Bondholders" (Minutes, Brazil, June 23, 1938).

Embassy officials also might be enlisted in actual negotiations. In the case of the $\mathrm{CFBH}$, embassy staff or even the ambassador himself might act as gobetween. Moreover, when initiating other transactions involving the debtor, the relevant government office might be prompted to hint that the bondholders would be receptive to a reopening of negotiations.

Finally, governments could link debt service to the provision of official credits, although the interests of bondholders usually took a back seat to other government objectives. U.S. Interior Secretary Harold Ickes articulated the administration attitude as follows, "There is no compulsion to invest in foreign enterprises and it ought to be at the risk of the investor" (Schuker 1988, p. 130). Similarly, as Sir John Simon of the British Foreign Office wrote in 1934, "My predecessor Lord Palmerston, who is not generally regarded as having been backward in the defence of British interests, laid down the doctrine that if investors choose to buy the bonds of a foreign country carrying a high rate of interest in preference to British Government Bonds carrying a low rate of interest, they cannot claim that the British government is bound to intervene in the event of default" (Abreu 1978, p. 118). Nonetheless, the government's growing involvement in other international financial transactions, such as extending its guarantee to certain trade credits, provided considerably increased scope for the exercise of leverage. In 1938, the British Treasury wrote the CFBH for a current list of countries in default, and expressed its desire "to make it a rule that the Treasury does not consent to issues of loans or to guarantees by His Majesty's Government to Medium Term Credits for countries which are in default to British bondholders. [The Treasury official] made it clear that he did not imply that the Treasury could make this an absolute rule and that, as at present, each case must continue to be considered on its own merits. He was, however, anxious to ensure that the Treasury should not give their consent without being fully aware of the defaults which exist" (Minutes, Foreign Loans, Feb. 24, 1938).

Similarly, in 1939 the U.S. special envoy to Peru warned that the prospects for future loans or credits from the U.S. "were nil" unless Peru signalled its good faith by resuming at least partial debt service (Gellman 1979, p. 40-44). Generally, however, intervention by the U.S. State Department was limited to instances in which foreign governments discriminated against U.S. bondholders. When Germany suspended debt service, European governments retaliated with threats of clearing arrangements, and Germany restarted service on its 
European but not its American debts. The State Department then went forward at the request of the FBPC "and made the appropriate representations" (U.S. Securities and Exchange Commission 1937, p. 390). The State Department similarly protested discrimination against holders of dollar bonds to the Hungarian and Polish governments and pressed for modifications of Brazil's 1934 readjustment on these same grounds. It was not the practice of U.S. authorities to make the extension of Export-Import Bank loans conditional on the resumption of debt service. But Export-Import Bank loans were highly politicized, and officials made clear that their progress could be accelerated by a gesture of good faith in the direction of the bondholders.

Pressure also could operate in reverse. The FBPC had been created on the impetus of the State Department, and the extent of its independence was never entirely clear. On a number of occasions, such as the Brazilian negotiations of 1943, the U.S. Embassy rather than the FBPC played the leading role. As Abreu (1978, p. 131) puts it, the "semi-official character of the FBPC led the institution to much more readily adapt its claims to American foreign policy." The CFBH had more autonomy. The U.K. government's attempts to enlist the Council in its alliance-building efforts intensified with the approach of World War II. In 1938, for example, the Council was engaged in negotiations with Egypt. For a time a settlement seemed imminent, but Egyptian officials added fresh conditions which caused the Council to retreat. The Foreign Office then pressed the CFBH to compromise on the grounds that "friendship with Egypt is of vital importance to the country." In July 1939, with the U.K. government anxious to conclude a treaty with Greece, the chancellor of the exchequer and the foreign secretary impressed upon the president of the CFBH the "political importance of a settlement of the Greek default." The president's interpretation was that the chancellor "in so many words . . advised us to take whatever was available" (Minutes, Egypt, Feb. 17, 1939; Minutes, Greece, Jan. 17, 1940). In both instances the Council successfully resisted the government's attempt to pressure it into immediate settlements which it considered unsatisfactory. Still, government pressure in 1938-39 may have had something to do with the fact that both cases were settled by 1940 .

Thus by the end of the 1930s creditor-country governments had become intimately involved in debt readjustments, although official intervention had ambiguous effects, on some occasions exerting pressure on the debtors but in others on the creditors.

\section{Trade as a Negotiating Tool}

To explain why debt repudiation is not commonplace, theoretical models of sovereign default posit the existence of a "default penalty" designed to capture the notion that nations which fail to service their debts provoke retaliation by creditor countries (Eaton and Gersovitz 1981; for a review of this literature, in much of which such assumptions are commonplace, see Eaton, Gersovitz, and 
Stiglitz 1986). Examples of retaliation might include loss of access to creditorcountry markets and inability to secure trade credits.

In the 1930s, members of the CFBH were divided over the advisability of using these levers. On the one hand, they recognized that retaliatory tariffs and trade credit embargoes served as powerful negotiating devices. On the other, they acknowledged that exports were the source of the foreign exchange that made debt service possible, so that discouraging exports hindered the resumption of service. Although other members of the CFBH generally supported an embargo on trade credits, the bankers argued that facilitating trade through the provision of credits was "the best way of liquidating a frozen position" (Minutes, Egypt, March 16, 1937).

The divergent interests of the financial and commercial communities undercut sentiment for retaliation. The extension of trade credits was a profitable business for the banks. Whereas long-term bonds had been underwritten by investment bankers and distributed to the public, short-term credits were retained by the original lender or sold to a select group of clients. Those engaged in a profitable import-export trade were loath to see their business suffer in the interest of foreign investors. On several occasions the representatives of the bankers reaffirmed that they were "unable to associate themselves with any attempt of the Council to oppose export credits to a defaulting country or to put the bondholders in a better position than the traders" (Minutes, Egypt, March 16, 1937).

For their part, the indebted countries attached considerable importance to trade credits. Even while debt service on foreign bonds was suspended, many debtor nations continued to service their commercial debts. The rationale was clear: although the bond market had dried up, the market for commercial credits was still active, providing an incentive for borrowers to stay current on their commercial debts. The CFBH implicitly endorsed these priorities, as in 1938, for example, when it recommended that "the sums at present being paid by Brazil as a result of agreements with England, France and the USA for commercial arrears, should be allocated to the service of the external debt as and when the commercial arrears are paid off' (emphasis added; Minutes, Brazil, Nov. 7, 1938).

The creditors' most potent threat was to enlist their government in the imposition of a clearing arrangement. This mechanism was available to any country running a trade deficit with a debtor country and hence with an excess of expenditures on foreign goods which it could sequester. The 1934 Act of Parliament creating a clearing office to regulate U.K. trade with Germany illustrates its operation. The clearing office was authorized to recover, out of the proceeds of German trade with the United Kingdom, a sufficient sum in sterling to pay interest on U.K. tranches of the 1924 Dawes Loan and the 1930 Young Loan. In practice, the mechanism would work as follows. U.K. purchasers would be required to pay for German goods by depositing the relevant amount of sterling in the clearing office. Exporters of goods to Germany would 
. $\quad$ then be paid in sterling from the funds which accumulated in the clearing office. Any surplus that accumulated would be devoted to debt service (see Einzig 1935). The potency of the threat is revealed by the speed with which a German financial delegation was dispatched to London, where it negotiated an agreement under which the United Kingdom would impose no sanctions against Germany, while Germany would continue to service the Dawes and Young plan bonds held by U.K. citizens.

The clearing arrangements threatened by Germany's European trading partners in 1934 were the exception rather than the rule. Germany itself had made extensive use of clearing arrangements (Ellis 1941, chap. 4) and could hardly invoke free trade principles in objection. Furthermore, the readiness with which European governments intervened reflected their direct involvement in the flotation of the Dawes and Young plan loans. Having urged their citizens to invest in German bonds, it was hard to insist that default was a private matter.

No such clearing was threatened by the United States against German trade, and from June 1934 on only partial interest was received by U.S. bondholders. In 1934 partial interest was paid out of the accumulated funds in the hands of the trustees. Thereafter bondholders were paid in blocked Reichsmarks, and from October 1935 they were given the option of selling their coupons for up to 70 percent of their face value in cash. All the while, European investors in these loans received full service (see FBPC 1935, pp. 217-18, and subsequent volumes; on the German response to the United Kingdom's threat of a clearing arrangement, see Eichengreen and Portes 1986 and the references therein).

In other cases, the position of the British Treasury, stated for example in connection with Greece in 1937, was that it was undesirable "to link together any question of purchase of Greek goods with negotiations for a settlement of the Greek External Debt." In the case of U.K. trade negotiations with Colombia in 1938, the head of the U.K. delegation, Sir Thomas Hohler, informed the CFBH that "he would not discuss the debt problem with Colombia but . . . would take any suitable opportunity to impress on the Colombians the importance from the point of view of their own credit of coming to an agreement over their external debts" (Minutes, Greece, March 18, 1937; Minutes, Colombia, July 14, 1938). Similarly, the Board of Trade stated that "if we now pressed the Colombians to settle their foreign debt, they would insist on linking this question with the trade discussions and ... neither we nor the Trade Mission make any headway." The board urged the Council to wait for trade discussions to end before pursuing the debt question (Minutes, Colombia, Nov. 17, 1938).

The U.S. State Department similarly opposed the linkage of trade and debt. In 1934 the FBPC attempted to convince Colombia that "increasing pressure is being brought both upon the Council and upon Washington by bondholders who are insisting that some sort of coercive measure shall be adopted against Colombia along the model set up by European countries or by levying a special tariff against Colombian coffee ..." (FBPC 1934, p. 95). Representatives of 
investors in Colombian bonds appeared before the Tariff Commission when a reciprocal trade treaty with Colombia was under consideration. Yet officials consistently resisted these representations. Sumner Welles, the Assistant Secretary of State, summarized the official position: "The position of the Department is that the primary purpose of the trade agreements negotiated under the Act of June 12, 1934 is the revival of international trade, and the agreement with Colombia does not, therefore, contain provisions specifically relating to the resumption of service of Colombian dollar obligations. However, inasmuch as the decline in international trade was one of the principal causes of financial difficulties in many countries, it is to be expected that the revival of international trade which the trade agreement program seeks to foster will aid in remedying conditions which have led to defaults" (U.S. Securities and Exchange Commission 1937, pp. 445-46).

Promises and threats concerning trade grew more common, however, with the outbreak of World War II. As the governments of the belligerents came to exercise increasingly comprehensive control of imports and exports, it could hardly be otherwise. Early in 1940 a Greek mission journeyed to London to meet with U.K. officials and negotiate trade arrangements. Waley of the Treasury conveyed to them that "the Chancellor of the Exchequer was anxious . . . to establish a market for their tobacco, but he could not defend such a course unless a settlement on the debt were reached ..." When Peru failed to remit interest for the first half of 1940, the British Treasury informed the Peruvian minister of finance that if the June coupon was not met, the U.K. government would be "obliged to reconsider their purchasing policy towards Peru."

In general, the U.S. government remained less interventionist. In 1943 the president of the Сғвн complained that although the United States was Brazil's principal market and principal source of credit, "the U.S. Government has not shown much regard for even its own Bondholders. In the interest of trade and of the Good Neighbour policy, it is lending money to Brasil regardless of Brasil's attitude toward its external bonded debt . . " (Minutes, Greece, Jan. 17, 1940; Minutes, Peru, June 13, 1940; Minutes, Brazil, Aug. 24, 1943).

Debtors too could link trade and debt. They repeatedly offered commodities in lieu of financial transfers in negotiations with the CFBH, offers which the Council rebuffed. In 1937 the Greek government proposed "that if Great Britain could take more currants, tobacco and iron ore it would enable them to make a better proposal for a permanent settlement." The 1940 imbroglio over tobacco had been initiated by Greece itself, which in 1939 had proposed U.K. purchases in exchange for debt concessions. The scope for such transactions widened with the approach of World War II and growing involvement of governments in trade. When in September 1939 the U.K. government purchased sunflower seeds from Bulgaria (in part to deprive Germany of them), Bulgaria agreed to allocate more than a third of the proceeds to the bondholders (Minutes, Greece, March 18, 1937; Minutes, Bulgaria, Nov. 7, 1939). 


\section{Discrimination among Creditors}

One of the main sources of tension between the U.K. and U.S. committees centered on the treatment of different types of bonds. On a number of occasions foreign governments, when renegotiating terms of repayment, chose to treat different debts in different ways. Some government obligations might receive very different treatment from others owing to previously obscure provisions of bond covenants assigning particular government revenues to debt service. Obligations of central, state, and municipal governments, although all renegotiated by national authorities, might receive very different treatment from one another. Treatment of debts incurred to finance specific investment projects might depend on how those projects had fared. These practices were highly controversial. The debates they elicited resemble controversies today surrounding proposals for exit bonds (which permit differential treatment for large and small creditors) and debt subordination (differential treatment for new and old creditors).

In many instances, foreign governments and bondholders' committees agreed in principle on the relative treatment different categories of bonds should receive. Foreign governments were more concerned with the creditworthiness of central than of state and local authorities. National governments could take over the service of state and local loans; hence changes in the creditworthiness of the national authorities had a much greater impact on that of state and local authorities than vice versa. When unilaterally reducing interest payments, debtors often scaled down interest on national loans by less than interest on state and local loans. Because suspending service on funding loans, which had been used to capitalize earlier interest arrears, was likely to remind creditors of the country's history of debt-servicing difficulties, debtors often extended these loans preferential treatment.

The attitude of the majority of creditors was embodied in a resolution adopted by the representatives of the national committees assembled at the Conference of Bondholders Associations in Paris in June of 1938. Loans to national governments had a claim to better treatment than loans to provinces or municipalities. Within each category, secured debt (debt for which specific revenue or security was earmarked) had priority over debt to be serviced out of general revenues. The resolution adopted at the Paris conference embodied the preferences of the $\mathrm{CFBH}$ which, as the most prestigious committee, heavily influenced the proceedings. The CFBH favored preferential treatment for secured debt by virtue of the fact that a disproportionate share of U.K. bonds were specifically secured. Its U.S. counterpart opposed differential treatment for the equally pragmatic reason that few dollar bonds were specifically secured.

The difficulties that could result are illustrated by the 1939 Colombian negotiations. The majority of Colombian debt was dollar-denominated, and officials were particularly concerned to satisfy U.S. bondholders and officials, 
because the United States was their largest export market. The CFвн noted the opinion that "the Americans were the only people who were likely to be able to make the Colombian government pay anything to its bondholders." Rather than initiating separate negotiations, the $\mathrm{CFBH}$ chose to let the Americans negotiate and then to attempt to secure the same treatment for sterling bonds. But when in early 1939 it appeared that settlement was imminent, in a letter to the FBPC the CFBH reported some "very strong feeling among the interests we represent that in any debt settlement some measure of practical recognition should be given to the preferential claims of the specifically secured loans." It was "not so much the amount of preference" to which they attached importance "as to some practical recognition of the principle . . ." (letter, April 25, 1939, $311 / 308)$.

The practical effect of extending preferential treatment to specifically secured loans would have been to elevate sterling bonds above dollar bonds. Neither of the two dollar bonds in default had specific security. Of the five sterling bonds, four had specific security: the receipts of the Bogota-Sabana Railway were earmarked for service of the 1906 loan, 3 percent of customs revenues were assigned to the 1911 loan, another 7 percent of customs receipts were earmarked for the 1913 loan, and a first charge on 5 percent of Atlantic customs revenues was assigned to the 1920 loan.

Not surprisingly, the U.K. claim to priority was rejected by the FBPC, which dismissed the difference between "so-called 'secured' and so-called 'unsecured' loans." In reply, the сгвн cited the resolution adopted in Paris in 1938. The CFBH regarded Colombia as a test case; as one of its officials wrote, "It seems to me important that we should if possible come to an understanding on the principle, since it is one which affects so many debt situations ..." (letter, May 17, 1939, 311/314; letter, June 5, 1939, 311/314A). The Council offered two justifications for preferential treatment of secured debt. First, bondholders had accepted lower interest rates in light of the special security offered. "Throughout the history of foreign lending," the CFBH noted, the market prices of secured loans had exceeded the prices of unsecured loans of the same debtor in reflection of this fact. Second, if this principle was not respected, future investors would attach little weight to specific security. For many countries, this would increase the difficulty of borrowing, "since it is precisely those countries which are temporarily passing through a difficult period, which are ... in most need of loans, and [for which] . . . the offer of special security has in the past often enabled their difficulties to be overcome." "To treat these differences as nonexistent," Sir Otto Niemeyer wrote the president of the Council, "cuts at the root of much past foreign lending and would, I believe, prove very nearly fatal to whatever chances there may be of foreign lending in the future" (letter, May 17, 1939, 311/314; letter, June 5, 1939, 311/314A; letter from Niemeyer to Lord Bessborough, Nov. 7, 1939).

The Americans, in response, questioned the meaningfulness of specific security, concluding that "these so-called 'securities' are not in fact securities, and 
... because they have not been effective against the funds designated the idea apparently is to give the bonds an actual preferential position on the general revenues and exchange of the country." What the British were seeking was to transform their claim to preferential access to specific revenues into a claim for preferential access to general revenues precisely when their claim to specific revenues had proven worthless. "To state this position is to answer it," the FBPC wrote. "No rule of equity or law could justify such a course."

The сғвн took legal advice before replying. Its central argument was that specific security implied "a contractual priority of payment to the specifically secured loans." It implied preferential access to general revenues rather than simply to earmarked revenues, since "it is common knowledge that it is no more possible by legal proceedings to sequester particular revenues than it is to sequester general revenues" (letter from the FBPC to CFBH, Nov. 19, 1939, 311 / 328; letter from CFBH to the FBPC, Nov. 29, 1939, 311/328A.). Ultimately, disagreement over the issue proved so profound as to undermine cooperation among the two bondholders' committees, leading them to conduct separate negotiations with Colombia. In 1940 the U.S. government superseded the FBPC and entered into direct negotiations with Colombia. The result was a settlement on the dollar debt, "distinctly generous" in the words of the СFBн, but nonetheless "strongly criticized" by the FBPC (Minutes, Colombia, Dec. 4, 1941).

Did discrimination help to normalize relations in the international capital market? No doubt preferential treatment of national loans permitted the resumption of meaningful levels of service where only token payments would have been possible otherwise. If creditworthiness depended more heavily on the status of national than of state and local loans, this could have been helpful for restarting international capital flows. But at the same time discrimination widened divisions between U.K. and U.S. bondholders and deepened creditors' resentment of debtors' actions. Discrimination was a two-edged sword.

\section{Repurchases of Defaulted Bonds}

Another technique for resolving disputes over defaulted bonds was for countries to buy the bonds at market prices. The practice was controversial. Bondholders complained that the practice violated not just the letter but the spirit of the bond covenants by diverting foreign exchange from debt service to capital repurchase (see, for example, U.S. Securities and Exchange Commission 1937, pp. 312-13, 496).

Repurchases indicated that foreign exchange was available; bondholders argued that it should be devoted to debt service until interest was up to date and only then to debt retirement. Permitting countries to repurchase defaulted bonds at market prices also strengthened the incentive to default, they alleged, for suspending debt service both depressed bond prices, making repurchase more attractive, and relaxed the foreign exchange constraint that limited the scope for bond market operations. Most important from the investor's stand- 
point, the low prices at which repurchases were attractive to the debtor implied disappointing rates of return compared with those offered ex ante. As the FBPC summarized the position: "If the bonds have service, according to their contracts, the debtor governments of course are well within their rights in availing themselves of the opportunity of purchasing the bonds on the market even if they are selling substantially below par but to do so when the bonds are depreciated abnormally on account of default ... is a practice which the Council most strongly condemns; against which it has repeatedly protested ..." (FBPC 1935, p. 12).

If small bondholders objected heatedly to the practice of repurchasing defaulted bonds, financial specialists noted that by entering the market and bidding for bonds, the foreign government put upward pressure on bond prices, ceteris paribus. Repurchases of defaulted debts were a way to eliminate costly lending mistakes. By removing the residue of nonperforming loans from the market, it would be possible to list new issues on the stock exchange and to get the lending process restarted. Repurchases were also resales-that is, voluntary transactions on the part of the bondholders-and as such represented the market solution to the problem of how to share the losses associated with an unsatisfactory loan.

Officially the CFBH opposed repurchases of defaulted bonds. When in 1938, with its defaulted debt trading at $£ 29$ (down from a par of $£ 100$ ), the Guatemalan government broached this issue with the Council, the latter advised that "if the Government now have funds available for the repurchase of bonds, the

Table 2. Brazil: Nominal Outstanding Public Foreign Debt, 1929-45 (millions of U.K. pounds)

\begin{tabular}{lccccc}
\hline Year & $\begin{array}{c}\text { Pound } \\
\text { loans }\end{array}$ & $\begin{array}{c}\text { Dollar } \\
\text { loans }\end{array}$ & $\begin{array}{c}\text { Franc } \\
\text { loans }\end{array}$ & $\begin{array}{c}\text { Guilder } \\
\text { loans }\end{array}$ & Total \\
\hline 1929 & 153.2 & 70.9 & 12.4 & 1.0 & 237.5 \\
1930 & 163.0 & 76.6 & 12.4 & 0.9 & 252.9 \\
1931 & 156.7 & 107.6 & 17.6 & 1.1 & 283.0 \\
1932 & 154.8 & 109.5 & 18.0 & 1.0 & 283.3 \\
1933 & 161.2 & 73.9 & 19.7 & 1.0 & 255.8 \\
1934 & 162.2 & 76.1 & 22.8 & 1.1 & 262.4 \\
1935 & 160.4 & 75.2 & 22.5 & 1.2 & 259.3 \\
1936 & 157.9 & 74.5 & 16.0 & 0.9 & 249.3 \\
1937 & 156.4 & 71.4 & 11.4 & 0.9 & 240.1 \\
1938 & 156.3 & 76.4 & 9.4 & 1.0 & 243.1 \\
1939 & 156.3 & 90.7 & 9.5 & 1.1 & 257.6 \\
1940 & 152.7 & 82.5 & 3.5 & 0.6 & 239.3 \\
1941 & 150.8 & 78.9 & 3.5 & 0.6 & 233.8 \\
1942 & 146.7 & 75.5 & 3.5 & 0.6 & 226.3 \\
1943 & 145.0 & 71.4 & 3.5 & 0.6 & 220.5 \\
1944 & 119.5 & 59.5 & 3.5 & 0.6 & 183.1 \\
1945 & 110.9 & 54.3 & 3.5 & 0.6 & 169.3 \\
\hline
\end{tabular}

Source: Abreu (1978, p. 107). 
proper course would be that they should offer to resume the Sinking Funds, in whole if possible, or if not, in part . . haphazard purchases of Bonds by the Government, at the time when the Sinking Fund is suspended on the ground of lack of funds would naturally be considered irregular and would do damage to their credit." The CFBH also noted the practical difficulties of completing large purchases in a thin market.

Yet the CFBH may have revealed its true attitude when it went on to suggest that "if a firm order were given at a price not exceeding, say 33, for the purchase of up to say- $£ 5000$ Bonds . . . it might be possible to complete the order in the course of a few weeks." Indeed, the CFBH accepted repurchase provisions as components of interim settlements. For example, in the four-year settlement with Brazil recommended by the Council in 1940, in addition to restarting partial interest payments the Brazilian authorities undertook to "devote at least $\$ 400,000$ in each of four years ... in the English market" (Minutes, Guatemala, Sept. 22, 1938; Correspondence, Letter from Aranha to Сғвн, Sept. 30, 1940, 241/1299; Minutes, Brazil, March 14, 1940).

\section{Brazil as a Case Study}

The extent of pragmatism, negotiation, and compromise between and among debtors and creditors is illustrated in the case of Brazil. Despite a long history of debt-servicing difficulties, Brazil had no trouble borrowing after World War I. Although Brazilians turned increasingly to New York in the $1920 \mathrm{~s}$, as late as 1929 nearly two-thirds of Brazil's external public debt was sterling-denominated (see table 2). Service on the external loans was interrupted in 1931 as default spread in Latin America. Brazil was forced into default by the Depression; continuing to service the public debt in 1932 would have required 45 percent of gross export receipts and nearly the same percentage of gross federal revenue. In August 1931 the government announced that it was unable to obtain sufficient foreign exchange to maintain service in full, choosing to suspend sinking fund payments on most loans while continuing to transfer interest. In October it unilaterally suspended interest as well on all except the 1898 and 1914 Funding Loans and the $7^{1 / 2}$ percent Coffee Institute Loan. These last assets were held mainly by U.K. investors, who owed their good fortune to the influence of Sir Otto Niemeyer, banker, former U.K. official and himself soon to become a member of the CFBH, then serving the Brazilian government in an advisory capacity.

The orthodox approach to disposing of interest arrears was to issue a funding loan, and in March 1932 a plan was announced to issue twenty- and forty-year funding bonds denominated in U.K. pounds sterling, U.S. dollars, and French francs. Coupons of the various central government bonds were to be exchanged as they matured for an equal amount of funding bonds. The plan was for normal interest payments to resume no later than 1934 (CFBH 1934, p. 11623). 
This dealt at least temporarily with the federal government debt but not with the obligations of states and municipalities. Not only did servicing these debts strain the budgets of the local authorities, but exchange controls imposed by the federal government in 1931 impeded transfers even by those with relatively strong budgets. Export volume remained depressed, and there was little prospect for obtaining another funding loan.

Finance Minister Oswaldo Aranha, with the advice of Niemeyer, crafted a plan to be in effect through 1937 to reduce debt service to levels consistent with Brazil's ability to pay. The most important precedents the plan established concerned discrimination and ability to pay. Service was limited to roughly 50 percent of Brazil's balance of trade. Bonds were divided into seven grades. Funding loans and the $7^{1 / 2}$ percent Coffee Realization Loan were to receive full interest; other federal, state, and local loans partial interest; and certain state and municipal loans no interest. Brazil was entitled to devote any remaining foreign exchange to market purchases of bonds in default.

Dissatisfied by the treatment of various dollar-denominated state loans (in Grade VI), the U.S. bondholders enlisted the State Department, and the U.S. ambassador was instructed to warn Aranha that discrimination against U.S. bondholders might provoke trade retaliation (Abreu 1978, p. 116). Negotiators for the Americans secured an improvement in the relative treatment of dollar bonds in Grade VI, which became Grade VII as the number of categories was expanded from seven to eight (see table 3). Neither was the CFBH satisfied with the outcome. It complained that by failing to consult systematically with the bondholders or to articulate the principles upon which the grading had been based, Brazil had created an "impression of arbitrariness." Much of the trouble, it was later alleged, resulted from the fact that Brazil had discussed the settlement with the issue houses but not with other interested parties (Minutes, Brazil, Dec. 14, 1939).

By the end of 1937 the external situation was little improved. Exports had risen only slightly and were now adversely affected by the U.S. recession. Foreign exchange derived from trade with Germany remained blocked. Efforts to maintain creditworthiness through continued interest transfers had not conferred an ability to borrow.

Even if the foreign exchange constraint could be relaxed, resistance to devoting resources to debt service continued to mount, especially within the Army, which took on an increasing political role in the Estado Novo established in 1937. Aranha later asserted that a price President Vargas paid for Army support in 1937 was to "stop payment on the debt and to let [the Army] have the money" (Hilton 1975, p. 186). Rather than renewing the Aranha Plan, Brazilian debt payments were suspended. Although the U.S. ambassador lodged a protest, U.S. reaction was restrained, reflecting the desire to advance Roosevelt's Good Neighbor Policy as well as U.S.-German animosities.

The United States and Germany accounted for a majority of Brazil's export trade, and in an effort to keep Brazil out of the German orbit, Roosevelt invited 
Table 3. The Aranha Plan: Brazilian Debt Service Schedule, 1934 (percentage of contractual rates)

\begin{tabular}{|c|c|c|c|c|c|c|c|c|}
\hline \multirow[b]{2}{*}{ Loan grade and description } & \multicolumn{2}{|c|}{1935} & \multicolumn{2}{|c|}{1936} & \multicolumn{2}{|c|}{1937} & \multicolumn{2}{|c|}{1938} \\
\hline & Interest & Principal & Interest & Principal & Interest & Principal & Interest & Principal \\
\hline $\begin{array}{l}\text { I } \\
\text { United States of Brazil } 5 \text { percent } \\
\text { funding loan, } 1898 ; 5 \text { percent } \\
\text { funding loan, 1914; } 20 \text {-year } \\
\text { bonds, 1931; 40-year bonds, } \\
1931\end{array}$ & 100 & 100 & 100 & 100 & 100 & 100 & 100 & 100 \\
\hline $\begin{array}{l}I I I^{\mathrm{b}} \\
\text { Federal-government secured }\end{array}$ & 35 & 0 & 35 & 0 & 40 & 0 & 50 & 0 \\
\hline $\begin{array}{l}I V^{\mathrm{b}} \\
\text { Federal-government unsecured }\end{array}$ & 27.5 & 0 & 27.5 & 0 & 30 & 0 & 40 & 0 \\
\hline $\begin{array}{l}\text { VI } \\
\text { Miscellaneous state loans }\end{array}$ & 20 & 0 & 22 & 0 & 25 & 0 & 35 & 0 \\
\hline $\begin{array}{l}\text { VII } \\
\text { Miscellaneous state and municipal }\end{array}$ & 17.5 & 0 & 20 & 0 & 22.5 & 0 & 32.5 & 0 \\
\hline $\begin{array}{l}\text { VIII } \\
\text { Miscellaneous state and municipal }\end{array}$ & 0 & 0 & 0 & 0 & 0 & 0 & 0 & 0 \\
\hline
\end{tabular}

Note: Principal payments were made into sinking fund.

a. Principal payments expressed as percentage of initial issue.

b. To be implemented after expiration of the 1931 funding plan.

Source: CFBH (1933, pp. 114-15). 
Finance Minister Aranha and a team of financial experts to Washington, D.C. In discussions, Aranha explicitly suggested that Brazil would be forced to turn to Germany if U.S. Export-Import Bank financing was not forthcoming (Wirth 1970, p. 107). In March 1939 the United States extended a $\$ 70$ million credit from the Export-Import Bank, $\$ 19$ million of which was to be used to liquidate frozen commercial claims and the rest of which was to finance U.S. exports to Brazil. As a gesture of goodwill, Aranha promised that Brazil would resume service on the external debt, paying at least $\$ 9$ million. But this was more than the Brazilian government and the Army in particular were willing to accept, and Vargas instructed the finance minister to deposit only $\$ 1$ million in New York (Dulles 1967, p. 204). Still, the U.S. Export-Import Bank loan went through.

U.K. reaction to the payment suspension was especially harsh, since it was felt that Brazil had defaulted for political rather than economic reasons. The CFBH also was concerned that the Americans might negotiate a separate settlement and took advantage of the opening provided by the U.S.-Brazilian negotiations to secure an assurance that Brazil would extend equal treatment to bonds of different currencies. In July the Brazilian government informed the bondholders' committees of its desire to initiate negotiations. Representatives of the U.S., U.K., and French committees met jointly with a special Brazilian commission.

Hopes for rapid progress were dashed by the outbreak of war. Germany had been Brazil's second most important customer, and the disruption of this trade clouded the prospects for Brazilian exports. Brazil and its creditors remained miles apart on the terms of permanent settlement. Brazil proposed a fixed sum for interest in the range of one-third of that provided under the Aranha Plan, sufficient to finance only a relatively low interest rate initially, but one that would rise as the operation of the sinking fund retired outstanding debt. The proposed rate of amortization (and hence rate of increase of interest) would be linked to the level of Brazilian exports. The СғBн objected to turning "a first debenture into a deferred equity" and countered with plans for a permanent settlement along the lines of the Aranha Plan (Minutes, Brazil, Jan. 11, 1940).

The outcome once again was a temporary settlement, supported by the United States, and by a $\$ 20$ million U.S. Export-Import Bank loan (increased eventually to $\$ 45$ million) (Wirth 1970 , pp. 116-17). In the four-year plan, the seven categories of bonds distinguished in 1934 were maintained, with somewhat modified interest rates. To avoid any implication that the bondholders had written off interest arrears, the CFBH insisted that payments made in the period 1940-44 were to apply to unpaid coupons from the period 193741 , and to mollify holders of sterling bonds on which interest had been reduced, the Council obtained a clause committing Brazil to repurchase some of these bonds on the market. The plan was to be reviewed no later than October 1943 (CFBH 1940, pp. I5-19).

Interest on the loans of the federal government and, with sporadic interrup- 
tions, of the states and municipalities was maintained throughout the life of the plan. By 1943 Brazilian officials felt the time was ripe for a settlement, given the country's large accumulated foreign balances and the growing competitive pressures Brazil was likely to face after the war (Abreu 1978, p. 126). From the beginning the Brazilians made clear that they were interested only in a permanent settlement and one "which would permit of a drastic writing down of the capital of the Debt" (сғвн 1943, p. 13). The bondholders' representatives opposed any compulsory writedown of principal, and they proposed that they be presented the option of either retaining their existing securities and receiving somewhat reduced interest rates or of selling back some share of the principal. Presumably the interest rate could be lowered to the point where the share of bondholders whose securities the Brazilian government wished to liquidate would come forward. In addition, the CFBH, anticipating that Brazil would have accumulated more foreign exchange to devote to debt service by the end of the war, preferred a temporary readjustment to a permanent settlement.

Ultimately the Сғвн was forced to accept a permanent settlement and modifications to the Aranha Plan which favored dollar bonds at the expense of sterling loans, reflecting the impact of U.S. economic ascendancy on the Americans' bargaining position. The offer announced in November 1943 is summarized in table 4 . Bondholders were initially given twelve months to choose a plan, those failing to specify being automatically included in Plan A. Under Plan A, which involved no liquidation of principal, interest rates were reduced to about 70 percent of contractual levels for Grade I loans and to around 30 percent of contractual levels for Grade VII. Plan B was suggested by the CFBH to provide an option for holders of bonds in Grades IV-VII likely to be disappointed by low interest rates and to satisfy Brazilian demands for capital reductions. Under Plan B, investors were to surrender 20-50 percent of capital, in exchange for which they would receive a cash payment (amounting to anywhere from 6-60 percent of the par value of the capital surrendered) and a somewhat higher interest rate ( 3.75 percent) on the remainder.

In addition to these graded loans, arrear coupons not included in the 1934 or 1940 plans were to be serviced at 10 or 25 percent of the payments due under the final year of the 1940 Plan. Some state and municipal loans were redeemed for 12 percent of their nominal value, with all arrear coupons canceled. Again, as additional foreign exchange became available, the Brazilian government was permitted to repurchase bonds in the market.

\section{How IT Ali WORKED OUT}

It is difficult to summarize concisely the outcome of a large number of debtor-creditor negotiations as complex as Brazil's. The only obvious way of doing so is by calculating rates of return realized by foreign investors and comparing those realizations with the returns offered ex ante and with the 
Table 4. Brazilian Debt Schedule of Payments, 1940 and 1943 Settlements

\begin{tabular}{|c|c|c|c|c|c|c|}
\hline \multirow[b]{2}{*}{$\begin{array}{l}\text { Loan grade and contractual } \\
\text { interest rate (percent) }\end{array}$} & \multicolumn{2}{|c|}{1940 Plan-fourth year } & \multicolumn{2}{|c|}{1943 Plan $A$} & \multicolumn{2}{|c|}{1943 Plan B } \\
\hline & Interest & $\begin{array}{l}\text { Sinking fund } \\
\text { as share of } \\
\text { contractual }\end{array}$ & Interest & $\begin{array}{l}\text { Sinking fund } \\
\text { as share of } \\
\text { contractual }\end{array}$ & $\begin{array}{c}\text { Capital } \\
\text { surrender }\end{array}$ & $\begin{array}{c}\text { Sinking fund } \\
\text { as share of } \\
\text { Plan A }\end{array}$ \\
\hline \multicolumn{7}{|l|}{$\bar{I}$} \\
\hline 5 & 2.5 & 40 & 3.375 & 70 & 20 & 120 \\
\hline \multicolumn{7}{|l|}{ II } \\
\hline 7 & 3.5 & 20 & 3.5 & 40 & 20 & 120 \\
\hline \multicolumn{7}{|l|}{ III } \\
\hline 5 & 1.25 & & 2.75 & & & 130 \\
\hline 6.5 & 1.625 & 0 & 3.375 & 25 & 20 & \\
\hline 7 & 1.75 & & 3.5 & & & \\
\hline 8 & 2 & & 3.5 & & & \\
\hline \multicolumn{7}{|l|}{ IV } \\
\hline 4 & 0.8 & & 1.5 & & & 162 \\
\hline 4.5 & 0.9 & 0 & 1.625 & 20 & 50 & \\
\hline 5 & 1 & & 1.75 & & & \\
\hline \multicolumn{7}{|l|}{ V } \\
\hline 7.5 & 1.40625 & 0 & 2.5 & 20 & 50 & 161 \\
\hline \multicolumn{7}{|l|}{$V I$} \\
\hline 5 & 0.875 & & 1.75 & & & 140 \\
\hline 6 & 1.05 & & 2 & & & \\
\hline 6.5 & 1.1375 & 0 & 2.125 & 10.5 & 50 & \\
\hline 7 & 1.225 & & 2.25 & & & \\
\hline 8 & 1.4 & & 2.5 & & & \\
\hline \multicolumn{7}{|l|}{ VII } \\
\hline 4.5 & 0.73125 & & 1.5 & & & \\
\hline 5 & 0.8125 & & 1.625 & & & 150 \\
\hline 5.5 & 0.89375 & & 1.75 & & & \\
\hline 6 & 0.975 & 0 & 1.875 & 10.5 & 50 & \\
\hline 6.5 & 1.05625 & & 2 & & & \\
\hline 7 & 1.1375 & & 2.125 & & & \\
\hline 7.5 & 1.21875 & & 2.25 & & & \\
\hline 8 & 1.3 & & 2.375 & & & \\
\hline
\end{tabular}

a. Sinking fund payments shown are those for sterling bonds.

b. In return for cash payments 3.75 percent interest was to be paid on remaining capital.

Source: CFBH (1943, pp. 15-16). 
yields on otherwise comparable domestic investments. In particular, the comparison of ex ante and ex post returns on foreign bonds provides an indication of how the losses on poorly performing loans were shared between debtors and creditors.

We summarize here the findings of our recently completed study which estimates the internal rates of return realized on two random samples of 250 dollar and 125 sterling issues floated in the 1920s (Eichengreen and Portes, forthcoming). ${ }^{3}$ An important element of these calculations was incorporation of repurchases of defaulted foreign bonds at market prices as well as normal interest and amortization. For dollar loans we were generally able to distinguish bonds retired at market prices and at par. For sterling loans this information was not readily available, so we constructed two rate-of-return estimates under the alternative assumptions that capital repayments took place at market price and at par.

The nominal internal rate of return for overseas issues overall (weighted by the value of the loan) averaged almost exactly 4 percent for dollar bonds, 5 percent for sterling bonds $(4.98$ percent when repurchases are assumed to have taken place at market price, 5.18 percent when they are assumed to occur at par). These results are striking for several reasons. First, the positive internal rates of return indicate that, on average, both U.K. and U.S. bondholders succeeded in recovering their principal. Second, the realized returns were significantly lower than those offered ex ante, which were generally in the range of 7-8 percent (for ex ante returns on dollar loans, for example, see Eichengreen 1988). On average, these bondholders settled for slightly less than half of contractual interest. Third, U.K. bondholders did better than their U.S. counterparts. ${ }^{4}$

A number of factors are likely to have contributed to the different experiences of U.K. and U.S. bondholders. Most important was the incidence of default. Nearly half the dollar bonds in the sample lapsed into default, but this was true for less than 20 percent of the sterling bonds. (These figures are shares of the value of sterling and dollar issues.) A greater share of U.K. lending went to dominions and colonies that were unlikely to interrupt service in the 1930s. In addition, once default occurred, U.K. bondholders recovered more success-

3. Our samples were comprised of all 125 London overseas issues listed in the Stock Exchange Yearbook between 1920 and 1929, and of a sample stratified by region and type of borrower (national government, state, municipality, and corporation) of 250 of the more than 1,400 U.S. foreign issues included in U.S. Department of Commerce lists. This is an expansion of our pilot study (Eichengreen and Portes 1986) to incorporate market-price repurchases of defaulted bonds, a larger sample size, and a longer time period.

4. The contrast between sterling and dollar returns here is relatively small compared with that in our pilot study. The difference is due largely to our having extended the sample period back from 1924 to the beginning of the decade (when loans bore higher interest rates) and our greater success in tracking the returns on loans to foreign corporations throughout the postwar period. Note that converting sterling investments and returns into dollars makes relatively little difference for the results. 
fully. The typical default reduced the internal rate of return by 4.3 percent on dollar loans, but by 1.4-2.3 percent on sterling loans.

It is interesting to compare these returns across all foreign loans with those received by Brazil's creditors. According to our calculations, the internal rate of return on dollar loans to Brazil was -0.2 percent, whereas the return on sterling issues was 1.1-2.3 percent. Given that all but one of the Brazilian loans in our sample (a dollar railway bond issued in 1922) fell into default, it is not surprising that the returns on Brazilian loans fell short of foreign investments as a whole. That U.K. creditors received a higher rate of return than their U.S. counterparts, despite the fact that every sterling loan to Brazil in our sample lapsed into default, reinforces our point that not merely the geographical distribution of lending but also ability to recover following default played an important role in determining bondholder experience.

What was the impact on realized rates of return of the controversial practice of buying back defaulted bonds at depressed market prices? To shed light on this question, we recalculated the internal rates of return on dollar bonds under the counterfactual assumption that all repurchases took place at par. Although in a small number of cases the difference was dramatic, the overall impact on the internal rate of return was slight. The estimated return on all dollar bonds rises from 4.00 to 4.96 percent (recall from above that the comparable figures for sterling bonds are 4.99 and 5.18 percent), with the internal rate of return on those bonds which lapsed into default rising from 1.64 to 3.58 percent.

\section{Conclusion}

Our review of the history of negotiations over the sovereign defaults of the 1930s suggests a number of conclusions relevant to the debate over today's developing-country debt crisis. First, the process of settlement tended to be protracted even before the era of interlocking official export credits, Paris Club reschedulings, IMF stabilization loans, and World Bank development assistance. Negotiations could suffer serious setbacks owing to changes in political and economic conditions both at home and abroad, and decades could be required to conclude a negotiated settlement successfully. Debtors may have found it easier to suspend debt service unilaterally in the era of bond finance, but they still found it difficult to achieve the kind of permanent settlement needed to put behind them the uncertainty created by default. This is not to dispute that by choosing unilateral suspension debtors were able to redirect toward investment and growth at least some of the resources that would have been used otherwise to service external debt. Rather, this strategy created residual uncertainty that continued to complicate foreign investment, trade, and diplomatic relations for a considerable number of years.

Second, although governments were less inclined to press for favorable settlements on behalf of private creditors in the 1930s because their banking systems were not at risk, it would be misleading to infer from this that governments 
were uninvolved. If governments were disinclined to intervene systematically on behalf of bondholders or to subordinate trade policy and political objectives to the interests of the bondholders, their presence was nonetheless continually felt in readjustment negotiations.

But did this creditor-country government involvement contribute positively or negatively to the ease of settlement? A case can be made that in the $1980 \mathrm{~s}$ it has contributed to the protracted nature of the crisis, but for the $1930 \mathrm{~s}$ the evidence does not point in any one direction. On a significant number of occasions, U.S. or U.K. officials made clear that export credits and market access were tied, however obliquely, to the resumption of reasonable levels of debt service. On others, they applied pressure not to the debtors but to the creditors. Because default did not pose the same risk to creditor-country banking systems as in the $1980 \mathrm{~s}$, the interests of private creditors and their governments did not possess the same obvious complementarity. And with the approach of World War II, creditor governments were more inclined to press for concessions from investors to keep the debtors out of the enemy camp. The strong contrast between the 1930s and 1980s lies not in the extent of government involvement but in the extent to which all government involvement worked in a single direction.

A number of the institutional features of the market for foreign debt also had an ambiguous impact on ease of settlement. Discrimination between different classes of creditors, notably the holders of secured and unsecured debt, permitted reasonable levels of service to be restarted on some obligations but fueled the objections of other bondholders. Buybacks of defaulted bonds were widely utilized and helped to remove the debt overhang, but at the cost of ill will on the part of small bondholders who objected to the practice.

The other factors considered all tended to increase ease of settlement. In the 1930 s, the provision of long-term finance and of trade credits was basically in the hands of two different sets of creditors who had divergent interests. The links between those arms of government concerned with trade and debt were remote. Divisions among creditors by nationality and competition among their governments also weakened the position of the lenders who usually were negotiating with representatives of a single entity, the debtor country's central government. In the $1980 \mathrm{~s}$, the United States has been permitted to take the lead in Latin America, as has Western Europe in relation to the Eastern Bloc, giving greater cohesion to creditor interests. All these factors have tended to make the crisis more protracted in the current period.

In light of this evidence from the 1930s, the difficulties faced in the negotiations of the 1980s should seem less surprising. In the earlier period, even with many factors contributing to a smoother and faster process, settlements often took decades to complete. But the range of approaches, the complexity of negotiations, and the profound influence of external political and macroeconomic factors all suggest that similar flexibility will be needed to work toward a resolution of the current crisis. 
Appendix A. Settlement of Defaulted Sterling Debts

Initial date shown is year of default; final date is year of permanent settlement except as noted (to 1967 only). Austria: 1939; $1954 .^{5}$ Brazil: 1931; a series of temporary settlements 1932-33, 1934-38, 1940-42; permanent settlement 1943. Bulgaria: 1932; temporary settlement 1934 only; 1948 settlement not implemented; still in default 1967. Chile: 1931; 1948. Colombia: 1932; 1944. Costa Rica: 1932; permanent settlement of 1955-56 implemented 1957. Czechoslovakia: 1939; agreement in 1946; redefault 1959. Offers discounted repurchase (1960) not recommended by Council, but it appears that it was carried out. Ecuador: 1929; settlement 1953; implemented 1956. El Salvador: 1935; settled 1936; redefault 1937; permanent settlement 1946. Germany: 1933; temporary settlement 1938-39; redefault 1939; permanent settlement 1953. Greece: 1932; temporary settlements in 1932, 1936; temporary settlement of 1937 refused by Council; temporary settlement of 1939, redefault 1941; temporary settlement of 1964 is implemented in 1965-66; permanent settlement 1967. Guatemala: sinking funds suspended 1933-43; repurchase offer (good for one year only) 1944. Hungary: 1934; permanent settlement 1937; redefault 1940; permanent settlement 1967. Italy: 1941; 1948. Japan: 1941; 1952. Mexico: 1914; 1942. Nicaragua: 1932; 1953. Paraguay: various periods of default 1915-17, 1920-24, 1932-43; permanent settlement 1944. Peru: Default 1931; part of debt settled in 1939; rest of debt settled by a plan in 1953 which was implemented in 1955. Poland: default 1937; settlement 1937-38; redefault 1939; settlement 1955. Rumania: default 1933; temporary settlements 1934 to 1940; redefault 1940; unsettled as of 1967. Uruguay: 1933; 1939. Yugoslavia: 1933; 1967.

\section{Appendix B. Settlement of Defaulted Dollar Debts}

Default and settlement dates on national government debt where "settlement" is defined as FBPC recommendation, or, where noted, FBPC acquiescence (to 1975 only). Initial date shown is year of default; final date is year of permanent settlement except as noted. Austria: default 1938, adjusted 1957. Belgium: partial default due to war 1941-46, adjusted by 1949. Bolivia: 1931-32, settled 1958, redefault 1960, resettled 1961, redefault 1965, resettled 1969. Brazil: default 1931-32, temporary settlement 1934-38, redefault 1938, permanent settlement 1944. Bulgaria: default 1932-33, partial payment (not formally accepted by FBPC) 1938-41, no permanent settlement as of 1975 . Chile: default 1931-32, partial payment offer of 1935 not recommended; partial payment offer of 1938 acquiesced to; permanent offer accepted 1948. Colombia: default 1931-33, one-year plan of 1935 accepted, one-year plan of 1940

5. Does not include pre-World War I debt of Austria-Hungary, which was assumed by the successor states. 
$\because \quad$ accepted, permanent plan of 1940-41 not recommenáed by FBPC but U.S. Department of State recommends it and 88 percent of bondholders accept as $\therefore \quad$ of 1944, permanent plan accepted by FBPC in 1949. Costa Rica: default 1932, three-year plan of 1939 accepted, no plan for 1942 until 1953 permanent plan accepted by FBPC. Cuba: default 1934, settled 1938, second default in 1960 not settled. Czechoslovakia: default 1939-40; plan of 1946 approved and implemented; redefault 1952; no settlement as of 1975. Denmark: default as to principal/sinking fund in 1942; adjusted by 1949. Dominican Republic:

- default in 1931 on sinking fund only, readjusted in 1934. Ecuador: 1908-10; 1955. El Salvador: default 1933; 1944 plan announced and 1946 plan implemented. Estonia: default 1940, not settled as of 1975. Germany: default 193234, FBPC accepts temporary plan 1934-36; settled 1953 (for national government). Greece: default 1932; temporary plan 1962-67 approved by FBPC (plan apparently became permanent). Guatemala: default 1932-33; while no formal plan was ever recommended by FBPC, the government of Guatemala redeemed its bonds in full with all interest arrears in 1944. Hungary: default in 1934; temporary offer accepted 1937-40; no further payments from 1942 onward; lump-sum and new bonds used to settle default in 1975. Italy: 1940; 1947. Japan: 1942; 1952. Mexico: default 1914; 1942 plan was implemented but not approved by FBPC, though they show the bonds as no longer in default after 1946. Panama: default 1935 and 1938; settled 1940, implemented in 1941. Peru: 1931-32; 1953. Poland: default 1935; settled 1938-39; redefault 1939; settled by lump-sum payment in 1975. Rumania: 1932-33; 1975 (lump-sum offer). Uruguay: 1932 (sinking fund)/1934 (interest); 1937. Yugoslavia: default 19.32; many temporary plans; to the 1938 Plan the FBPC said "cannot recommend that bondholders decline this (1938) offer"; redefault in 1939; 1959 plan implemented in $1960 ; 1964-67$, temporary plan; 1967 , permanent plan.

\section{REFERENCES}

Abreu, Marcelo de Paiva. 1978. "Brazilian Public Foreign Debt Policy, 1931-1943." Brazilian Economic Studies 4: 105-40.

CFBH (Corporation of Foreign Bondholders). Various years. Annual Report of the Council of the Corporation of Foreign Bondholders. London.

Diaz-Alejandro, Carlos. 1983. "Stories of the 1930s for the 1980s." In P. Aspe Armella, Rudiger Dornbusch, and Maurice Obstfeld, eds., Financial Policies and the World Capital Market: The Problem of the Latin American Countries. Chicago: University of Chicago Press.

. 1987. "Some Aspects of the Development Crisis in Latin America." In Rosemary Thorp and Laurence Whitehead, eds., Latin American Debt and the Adjustment Crisis. Pittsburgh: University of Pittsburgh Press.

Dulles, John W. F. 1967. Vargas of Brazil. Austin: University of Texas Press. 
Eaton, Jonathan, and Mark Gersovitz. 1981. "Debt with Potential Repudiation: Theoretical and Empirical Analysis." Review of Economic Studies 48: 289-309.

Eaton, Jonathan, Mark Gersovitz, and Joseph Stiglitz. 1986. "The Pure Theory of Country Risk." European Economic Review 30: 481-514.

Eichengreen, Barry. 1988. "The U.S. Capital Market and Foreign Lending, 19201955." In Jeffrey Sachs, ed., Developing Country Debt and Economic Performance. Vol. 1. Chicago: University of Chicago Press.

Eichengreen, Barry, and Richard Portes. 1986. "Debt and Default in the 1930s: Causes and Consequences." European Economic Review 30: 599-640.

-. 1987. "The Anatomy of Financial Crises." In Richard Portes and Alexander K. Swoboda, eds., Threats to International Financial Stability. Cambridge, Eng.: Cambridge University Press.

- Forthcoming. "After the Deluge: Default, Negotiation and Readjustment of Foreign Loans During the Interwar Years." In Barry Eichengreen and Peter Lindert, eds., The International Debt Crisis in Historical Perspective. Cambridge, Mass.: MIT Press.

Einzig, Paul. 1935. The Exchange Clearing System. London: Macmillan.

Ellis, Howard S. 1941. Exchange Control in Central Europe. Cambridge, Mass.: Harvard University Press.

Feinstein, Charles. 1972. National Income, Output and Expenditure of the United Kingdom, 1855-1965. Cambridge, Eng.: Cambridge University Press.

Feis, Herbert. 1930. Europe, the World's Banker, 1870-1914. New Haven, Conn.: Yale University Press.

Fischer, Stanley. 1988. "Resolving the International Debt Crisis." In Jeffrey Sachs, ed., Developing Country Debt and Economic Performance. Vol. 1. Chicago: University of Chicago Press.

Fishlow, Albert. 1986. "Lessons from the Past: Capital Markets during the 19th Century and the Interwar Period." In Miles Kahler, ed., The Politics of International Debt. Ithaca, N.Y.: Cornell University Press.

FBPC (Foreign Bondholders Protective Council). Various years. Annual Report. New York: FBPC.

Gellman, Irwin F. 1979. Good Neighbor Diplomacy: United States Policies in Latin America, 1933-1945. Baltimore, Md.: Johns Hopkins University Press.

Hilton, Stanley E. 1975. Brazil and the Great Powers, 1930-1939. Austin: University of Texas Press.

IMF (International Monetary Fund). 1983. "International Capital Markets: Developments and Prospects." Occasional Paper 22 (July).

Jenks, Leland H. 1927. The Migration of British Capital to 1875. Cambridge, Mass.: Harvard University Press.

Lindert, Peter. Forthcoming. "Response to the Debt Crisis: What Is Different about the 1980s?" In Barry Eichengreen and Peter Lindert, eds., The International Debt Crisis in Historical Perspective. Cambridge, Mass.: мIт Press.

Lindert, Peter, and Peter J. Morton. 1988. "How Sovereign Debt Has Worked." In Jeffrey Sachs, ed., Developing Country Debt and Economic Performance. Vol. 1. Chicago: University of Chicago Press. 
OECD (Organisation for Economic Co-operation and Development). Various years. Main Economic Indicators. Paris.

- Porzecanski, A. 1983. "Profitability of International Banking." In E. Roussakis, ed., International Banking. New York: Praeger.

Royal Institute of International Affairs. 1937. The Problem of International Investment. London: Oxford University Press.

Sachs, Jeffrey. 1986. "Managing the Debt Crisis." Brookings Papers on Economic Activity 2: 397-431.

- Schuker, Stephen A. 1988. “American 'Reparations' to Germany, 1919-33: Implications for the Third-World Debt Crisis." Princeton Studies in International Finance 61 (July).

- Skiles, Marilyn. 1988. "Latin American International Loan Defaults in the 1930s: Lessons for the 1980s." Federal Reserve Bank of New York Research Paper 8812. New York.

U.S. Department of Commerce. 1976. Historical Statistics of the United States. Washington, D.C.: U.S. Government Printing Office.

U.S. Securities and Exchange Commission. 1937. Report on the Study and Investigation of the Work, Activities, Personnel and Functions of Protective and Reorganization Committees, Part V: Protective Committees and Agencies for Holders of Defaulted Foreign Bonds. Washington, D.C.: U.S. Government Printing Office.

Wirth, John D. 1970. The Politics of Brazilian Development, 1930-1954. Stanford, Calif.: Stanford University Press. 